\title{
Rational Choice Theory and Political Counsel
}

Catus Brooks* and Jocelyne Praud

Department of Humanities, University of Victoria, British Columbia, Canada

*Corresponding author: Catus Brooks, Professor, Department of Humanities, University of Victoria, British Columbia, Canada, Tel: 1-250-721-7211; E-mail: sirgraciousness@gmail.com

Received date: March 01, 2018; Accepted date: March 08, 2018; Published date: March 15, 2018

Copyright: $\odot 2018$ Brooks C, et al. This is an open-access article distributed under the terms of the Creative Commons Attribution License, which permits unrestricted use, distribution, and reproduction in any medium, provided the original author and source are credited.

\begin{abstract}
Continuing our discussion regarding political counsel in the history of political thought, there is a problem of futurology concerning good governance without accurate predictions when science recedes into mere metaphysics, and so counsel must occupy the clock tower, like the hilltop. When our science is still coming to an order, then we rely on fictional devices in political rhetoric. We must guard against those whom blame us for fictitious prose; as Aristotle reminds, without sight one cannot pass a judgement. Dialectics is an educational method used by political theorists, and to keep vivacity we will apply the story-telling of Plato the dialogian and Niccolo Machiavelli the Classicist. Dialogue is a fictional form of dialectics and Classical story-telling, though not classified in dialectics according to Aristotle, is an invention necessary to the student of doing. Plato once said, the tale has a truth to tell. As contestants we will need to choose a terrain to hunt on. This strategic inquiry consists of rational choice theory from Machiavelli's beaten path in Ch. 6 of The Prince, Plato's roads in his Laws, from Hesiod's Works and Days, and some foresight regarding their problems of futurology in rational choice theory and consultancy.
\end{abstract}

Keywords: Social; Science; Sociology; Humanities

\section{Introduction}

Continuing our discussion regarding political counsel in the history of political thought, there is a problem of futurology concerning good governance without accurate predictions when science recedes into mere metaphysics, and so counsel must occupy the clock tower, like the hilltop. When our science is still coming to an order, then we rely on fictional devices in political rhetoric. We must guard against those whom blame us for fictitious prose; as Aristotle reminds, without sight one cannot pass a judgement [1]. Dialectics is an educational method used by political theorists, and to keep vivacity we will apply the storytelling of Plato the dialogian and Niccolo Machiavelli the Classicist ${ }^{1}$. Dialogue is a fictional form of dialectics and Classical story-telling, though not classified in dialectics according to Aristotle, is an invention necessary to the student of doing ${ }^{2}$. Plato once said, the tale has a truth to tell $[2]^{3}$. As contestants we will need to choose a terrain to hunt on. This strategic inquiry consists of rational choice theory from Machiavelli's beaten path in Ch. 6 of The Prince, Plato's roads in his Laws, from Hesiod's Works and Days, and some foresight regarding their problems of futurology in rational choice theory and consultancy.

- Plato: "Is it not proper that I, as the elder, should answer first?" [3].

- Machiavelli: "I object old man, for there is, says Fortune, a common opinion that hunts are won by the young."

- Plato: "But a man's vision of such objects is at its dullest when he is young, but at its keenest when he is old." [3].
- Machiavelli: "Change dictates survival; chance the prize and contest."

\section{Review}

Machiavelli knew practical wisdom in rational choice theory: before the statesman can charge to Victory with suretyship, one requires rational choice theory for the best plan, especially when the plan is overly-general [1]. Machiavelli seeks to provide a course with various alternatives for his advisee, Lorenzo de' Medici, to reason about; he leaves them with rational options to adopt from the history books. His form of rational choice theory is empirical proper, as he wishes that his advisee imitates the best political actors from history [2]. His beaten path he believes is the road to Victory, for the talents, traits, and actions of these rulers are worth following in rational choice theory [2]. If Medici lacks the practical experience necessary for statecraft, and there is no science that can fortune-tell the best decisions in politics, then aspiring in imitation to the worthiest rulers is a ready plan ${ }^{4}$.

What if following these rulers, their traits, their actions, was irrational? Plato takes an opposing stance in futurology for rational decision-making. According to Plato's Athenian, in the words of Hesiod, "smooth is the way that leadeth unto wickedness ... no sweat is needed to traverse it" [3]. Plato continues,

In front of goodness the immortal gods

Have set the sweat of toil, and thereunto

Long is the road and steep, and rough withal

The first ascent; but when the crest is won,

1 The name Niccolo derives from the Greek Nike.

2 See Thomas Hobbes, The Leviathan, for the conceptualization of invention, as a kind of sagacious seeking $(1994,13)$.

3 Remember that Plato was a Peripatetic, a kind of political counsel while discovering, which came prior to empiricism.

4 Remember that history as an art is embedded in Roman culture, as they advanced it from the Greeks. Medici was versed in history, and we can infer this fact from Machiavelli's style of address to him. 
Page 2 of 2

'Tis easy travelling, albeit 'twas hard [3].

In Ch. 6 of The Prince, Machiavelli's road to glory is a gamble, it is short, unconstitutional, and spiteful; Romulus murdered his brother, Moses his father. Plato would not idolize these characters or their style, about them he would not even wonder. His Athenian's consultation suggests for Clinias of Crete, the learner, to rate defensive physics over the way of comfort [3]. If the comfortable path changes back and forth from spite to indolence, and the long and steep road leads to exertion, then Plato's ruler wins his constitution.

Further, Machiavelli aims to course his advisee in the footsteps of Theseus, Moses, and Romulus, in aspiration of their deeds. Machiavelli's approach here to counselling is intuitive; as an expert, he can advise Medici to take the course that was completed times before, or close to it [2]. With Machiavelli's futurology, he sets up a framework for Medici to intuit solutions to difficulties, and the lack of clarity in The Prince does not pose difficulties for Medici if he was a beginner in statecraft whose sensibility moves to Machiavelli's basic empiricism, if Medici intuits to the fun of glory, rather than the schoolmen's criticism $[4]^{5}$. Machiavelli visualizes a task for Medici to overcome ${ }^{6}$, with an intuitive vision grounded on unpredictability: terra incognito and uncharted oceans had the interest of the secretary in him.

Plato asks Machiavelli in reply, "are you aware of the irrationality of intuition on a road without a map? A foolhardy empire ${ }^{7}$, save the children! Scholars of rational choice theory have divided on this question frequently". Plato's Athenian asks, "what conduct, then, is dear to God and in his steps?" [3]. Victory in hunting, accuracy with spears, justness and then moderation and temperance, foresight and a calendar, rules for the wicked, and honors paid and right conduct. There are "duties for children, relations, friends, and citizens" [3]. The course to discipline is at times mean and others moderate, for the blessings of prosperity and against adversity.

\section{Discussion}

The above-discussion courses over questions of futurology, a framework in rational choice theory that is free-form, much like political thought generally ${ }^{8}$. Machiavelli left alternative ways down a path for Medici to travel and Plato convinced the stranger Clinias of the worth of wroth on the road up the Mount [5]. This debate points to Machiavelli and Plato's direction with consultation strategies regarding rational choice theory: Machiavelli aims to inspire Medici with intuitive governance and Plato's Athenian aims to educate Clinias with compulsory rules.

Intuition may be immeasurable; but, if choices are limited, intuition can still be rational to win in power; whereas, compulsory rules may be right to hold a constitution together, as a constitution cannot be irrational. Howbeit, there may be shortcomings to rational choice theory without a science yet, but we will limit the discussion now in contentment with practical sagacity.

\section{References}

1. Aristotle (1995) Complete works of Aristotle, Volume 2: The Revised Oxford Translation.

2. Thomas H (1994) Leviathan with selected variants from the Latin edition of 1668 .

3. Plato (1926) Laws (Book I-VI). Translated by R. G. Bury

4. Herman K (1975) "On Studying the Future." In Handbook of Political Science: Strategies of Inquiry $7: 405-442$.

5. Niccolo M (1994) Selected Political writings: The Prince, Selections from the Discourses and Letter to Vettori.

5 In the literary sense not clear-sight in battle.

6 task for Medici to overcome

The term empire is a derivation of empiricism.

$8 \quad$ See Herman Kahn. 1975. “On Studying the Future." 